enough to be of practical engineering value in estimating probable effects on structures.

In Great Britain very few earth tremors and no large earthquakes are experienced, but earthquake regions do exist in the British Dominions and Colonies, and British insurance companies often have interest in regions subject to earthquakes. It is well to point out that a body of information on strong-motion seismology does exist and that methods are available to those interested for the study of problems relating to the construction of earthquake-proof buildings. In various parts of the world building codes are in operation, and in such of these areas as are subject to earthquakes, buildings, bridges, dams and other structures financed in part or wholly from public funds, together with such structures as are built under the control of the authority, are designed in some measure to withstand earthquake stresses. It cannot be too strongly emphasized that this part of seismic science is progressing rapidly and that a study of observations obtained either from natural phenomena or from experiments, in addition to providing us with useful information, enables us to ask more intelligent questions in the future.

1 NATURE, 146, 437 (1940).

2 United States Earthquakes, 1938. U.S. Dept. Commerce, Coast and Geodetic Survey, Washington, Serial Number, 629, by Frank Neumann (1940).

\title{
PRESERVATION OF THE BRITISH FLORA*
}

\author{
By Dr. J. Ramsbottom, O.B.E.
}

$\mathrm{M}$ ANY societies, leagues, associations and other bodies have concerned themselves in the past with the preservation of native British plants. The appeal is often made on æsthetic grounds. This is a sound policy, but occasionally it has seemed to get a little out of hand, and even sometimes to have defeated its object.

It is probable that far more damage is done by trampling down the plants than by picking the flowers. Many plants, as for example the common heather or ling, cannot endure trampling, whereas the effect of picking the flower of a bulbous plant is seen with daffodils and tulips every year in our gardens. Reasonable and careful picking of the commoner wild plants does little harm, and the joy that comes from flowers is one that it seems senseless to chide. It is really at bottom the spirit that prompts crowds to flock to Kew, Hyde Park, Bushey Park, Hampton Court, etc. This spirit should be encouraged in other directions.

Most of our attractive wild flowers are so abundant that little harm follows a reasonable amount of picking. The digging up of plants is a totally different matter. Plants with a successful method of reproduction such as bulbs, or corms, and perennial plants, do not disappear if only the flowers are removed: other plants suffer only in so far as there is a loss of seed production. But it is obvious that if plants are dug up there will be a gradual disappearance, no matter whether they are as prolific as are primroses and ferns in the southwestern parts of England. Practically every civilized country has recognized the danger; in most there are societies which have laws pro-

* From the presidential address to the Botanical Section of the Bouth-Fastern Union of Scientific Societies, delivered at Kingston-onThames on July 26. hibiting activities subversive to the welfare of the native flora.

In 1931 many societies, councils and institutes which are interested in various aspects of plant preservation elected representatives to the Wild Plant Conservation Board, which works under the auspices of the Council for the Preservation of Rural England. In 1914 the Selborne Society, through its Plant Protection Section, had prepared a Bill for presentation to Parliament, but legislative action was prevented by the outbreak of war. However, there is a good deal of scope provided by the Local Government Act of 1888, which empowers county councils to adopt by-laws for the preservation of wild plants.

Botanists and ornithologists have viewed with concern the effects of cutting verges and lopping hedges in country lanes. Here we meet with difficulties. The lanes must be kept tidy if on no other grounds but those of safety to users. There are various weeds which the Corn Production Acts say the farmer must destroy, and it is unreasonable to expect him, or roadmen, to carry out this obligation if botanical discrimination is added to the task. There are signs, however, that some county councils realize that there is no necessity for ruthless and indiscriminate cutting, or that spring or early summer is necessarily the period for the tidying process.

With rarer plants the problem is different. Some of these are unattractive to the non-botanist and are not likely to suffer except through excessive collecting. One or two are reputed to have vanished on this account, and the evidence from herbarium sheets gives support to some of the accusations that have been made. 
On the other hand, some of the rarer plants are showy. An attractive plant may be protected because of surviving in more or less inaccessible places, such as the Cheddar pink. It seems to me that the only way to ensure the safety of others is to arouse a local interest in their protection. Local pride would do a good deal to preserve such rarities, especially if the habitats were known and the danger of extinction appreciated.

But there is also a wider problem which is not concerned with thoughtless or witless destruction. At the time of Cæsar's invasion of Britain we know that it was largely forest. During the Roman occupation much of the land was cleared and roads were built. With the cutting down of forests there is a difference in rainfall and always soil erosion, sometimes, as is more clearly understood in those countries which are paying the price, to the extent of causing deserts. When roads are made there is always an alteration to the drainage. With the building of towns cattle were put to pasture rather than driven from place to place. From all these processes at work there must have resulted an enormous influence on vegetation. I am not suggesting that any species were lost, though there might well have been. On the whole the number of species in the British flora is small; this is explained by the fact that more were not able to advance into Great Britain after the last retreat of the ice. The Channel has acted as a barrier to the invasion of plants from the Continent. If, therefore, any plant species were wiped out, that finished the matter; they did not come again.

The settlement by the Romans started changes which have continued to the present day. The old highways with their droves of cattle and wide expanse must have had an enormous influence on vegetation and consequently upon individual species. Later the spread of towns and the effect of smoke and other pollution consequent upon this have all had their destructive effect. The drainage of the Fens which began in the Middle Ages enormously affected the vegetation of the areas concerned. Neither must we forget the effects of farming, forestry and other forms of cultivation.

What we get as a gradual effect of civilization is an alteration in or a destruction of primitive vegetation. The change has taken place and most of it could not have been prevented even if this had been desirable.

As London extended, known localities of rarities were built over. Some of the habitats mentioned in the herbals now make strange reading. The one probably most quoted is that of the small bugloss given in Johnson's edition of Gerard's "Herbal", 1633, Buglossa sylvestris minor (Lycopsis arvensis)"On the drie ditch-bankes about Pickadilla".

The lost habitats best known to London botanists are those of Battersea Fields, Chelsea Fields and Brompton Marshes, which disappeared as the Thames Embankment was built. A number of interesting species remain between Putney and Kew. Clusius, in his "Historia Plantarum Rariorum" (1601), records that the daffodil was "in such abundance in the meadows close to London, that in that celebrated village of Ceapside the country women offer the flowers in profusion for sale in March, when all the taverns may be seen decked out with these blossoms"; L'Obel (1605) also says, that in February and March the London flower-market is full of it.

Such losses are inevitable. As towns spread, especially in the old haphazard way, places famous as collecting-grounds from the time of the herbalists become just building sites to be developed. London has been fortunate in having royal parks and commons which are sterilized against such development; and a far-sighted policy reserved such forests as Epping and Burnham Beeches and is now organizing a green belt.

It is possible by sensible town planning not only to arrange proper means for fresh air and recreation for everyone, but also to prevent the sprawling ribbon development which has made some by-pass roads by-words. There are certain other consequences which it would be out of place here to mention. The point that can be legitimately made is that the countryside around such roads is ruined.

We are faced, however, with a much more serious problem at the present time as a direct result of the War. Aerodromes and military camps have multiplied over the countryside, and the carrying out of various exercises and other preparations for defensive or offensive war have made a sorry mess of some areas. I simply state the fact about our flora just as I would about the destruction of many famous buildings : it would be absurd to do more considering all that is at stake. Before the outbreak of war the Air Ministry paid due attention to the representation of those interested in different ways in the areas in which it was proposed to build aerodromes, and I understand that, even under the strain and stress of war, regard has been paid so far as is expedient to what is now popularly styled the amenities of the countryside. This enlightened policy is one of the most hopeful signs that we may look forward to the after-war period as one of 'reconstruction' in every sense of the word. It is obvious to everyone with eyes to see that there are a great many new blots on the landscape. After the War it may be that some of these will have to remain, but it should be a definite policy to remove, so far as possible, those which are no longer serving the purpose of national defence. Moreover, it may not be amiss to suggest that when an area is in occupation by H.M. Forces, 
vegetation should not be wantonly or carelessly damaged. Trees which are knocked about, for example, do not invariably survive-and trees do not grow in a night.

Let us see to it that when salvaging our material possessions after the War we take care that our countryside is looked after.

When the time comes local bodies should make it their aim to get rid of all objectionable signs of war activity in their areas and they should be pressed to do so by local natural history societies. A derelict camp still with obvious signs of previous occupation is a sad sight, and does not improve with the years. Heaps of bully beef tins and other refuse left by our troops in the South African War are still to be seen in some parts of the Karroo. Organic material is soon dealt with by fungi and bacteria, but bricks, petrol tins and barbed wire are beyond their efforts.

In recent years there has been a strong movement on the part of several societies and associations for the establishment of national parks: roughly the objects they have in view may be classed as landscape preservation, public access and protection of wild life.

The idea of national parks seems to have been put forward first in 1832 by George Catlin, who suggested that the country around the geysers near the head of the Yellowstone River should be reserved as a public park.

The Yellowstone Park, sixty-five miles long by fifty-five miles broad, was reserved in 1872. The Oxford Dictionary defines a national park as "an extensive area of land of defined limits set apart as national property to be kept in its natural state for the public benefit and enjoyment". The definition is excellent so far as it goes, but there may be differences of opinion about the interpretation of the words "public benefit and enjoyment". The national park movement has spread rapidly in those countries where there are great stretches of unaltered vegetation. In Great Britain it is obvious that we cannot emulate Yellowstone Park, Jaspar Park, Kruger Park, that of Belgian Congo or those of Angola and the islands of the Gulf of Guinea now under consideration by the Portuguese Government.

What it is possible to do should be carefully considered-and then done Probably nowhere in southern England-though possibly in the north, in Wales and in Scotland-could we fix on an area sufficiently extensive to fulfil all the objects in view. But this does not mean that no attempt can be made to preserve tracts of countryside representative of our scenery. These tracts may be called national parks, or what you will; they should be sufficiently extensive and isolated not to suffer from suburban suffocation.
Recreation is a vital necessity for the public if there is to be real health of body and mind, but there is no reason why this should not proceed hand in hand with preservation. Sanctuaries could be set aside in the larger areas for preserving any species which need protection, in addition to smaller areas scattered about the country as nature reserves. If the public are educated up to it they will demand that such species be protected; education is more effective than Verboten-just as "Reserved for the protection of ..." is than that wooden lie "Trespassers will be prosecuted". The way in which the general public obey some very annoying present-day restrictions gives ample proof of the fact that a law or regulation is the more powerful the more the reason for it is comprehended.

Strange as it may seem, it is often overlooked that it is the vegetation which is the key to the position. If plants are preserved then the scenery remains pleasant, and birds, animals and insects are for the nost part safe. Perhaps the best way to appeal to the public is to make a point about the scenery: "Preserve the country's scenery"-and the rest follows. The general aim could then be stated as the desirability of preserving the various types of representative British scenery in sufficient numbers as to be reasonably accessible.

It is obviously impossible to sterilize a sufficiently large area in the British Isles to include all types of scenery or vegetation. The type of vegetation depends in the first instance upon the character of the soil, the altitude and the amount of rainfall, and as any large park or parks would need to be in a mountainous district we obviously canncit envisage such a park as providing an epitone of the country's vegetation. For that we must have several areas and, for special protection, areas set aside in these. No plan will succeed which attempts to exclude free access by the public. Those of us who know Richmond Park, Wimbledon Common, Burnham Beeches, Epping Forest and Virginia Water will have no qualms about the bad effect of open access to pedestrians. But it would be advisable to restrict motoring and horseriding. Motoring brings obvious evils in its train, and those following excessive horse-riding in Epping Forest were causing an outcry in the last year or two.

The prevalent opinion seems to be that where areas are set apart for preservation Nature should be left to its own devices and then all would be well. In Switzerland each canton has its laws for the preservation of plants and there are several Nature reserves; there is also the Swiss National Park situated in the Lower Engadine. Here the following rules and regulations are in force. Human interference is absolutely excluded from 
the whole region. Shooting, fishing, manuring, grazing, mowing and wood-cutting are entirely prohibited, no flower or twig may be gathered, no animal killed and no stone removed - even the fallen trees must remain untouched. In this way absolute protection is secured for scenery, plants and animals: Nature alone is dominant. Any one may visit the Park, but only simple Alpine shelterhuts are provided, no hotels being allowed to be erected. Camping and the lighting of fires is prohibited.

Some would like similar regulations made for any national park we might have. But it should be pointed out that only in areas of primitive vegetation is it possible to leave well alone and be certain that it will not alter. The vegetation of Great Britain as it is now is largely the result of interference; many of the types of vegetation are not as they would be if they were not controlled by various factors. So long as these factors remain the same, the vegetation remains the same. Taking it as a whole the vegetation of Great Britain is not static. For every type of soil there is a type of vegetation which is called a climax and there is a natural gradual change towards this. Everyone must have noticed hawthorn and other bushes 'invading' grassland adjoining woodland, but it is not always realized that this is a natural process leading to the climax vegetation-for forest is the climax.

The idea is often expressed that "Education of the average adult to respect our wild flowers may seem well-nigh hopeless. He is not interested". Certainly the normal place for beginning education is the school, and much can be done there to inculcate a proper appreciation of our native scenery and the duty of preserving vegetation from spoliation. But education does not end at school, and the B.B.C. and the cinema have brought home to many an interest in green things growing.

When the present War is over it is possible that eventually there will be many changes in our normal mode of life. Maybe some benefit other than speed will accrue from the increase in the use of mechanical devices. To one not versed in the refinements of economics the conclusion seems justified that if work is done more quickly by fewer men there must either be unemployment or shorter hours. We certainly had unemployment before the War, and in the future reconstruction we may well look for shorter hours for those engaged in manual labour, though not I fear for the rest of us. If this desirable state of affairs eventuates we are then faced with the basic problem of education, how to spend one's leisure time.

When leisure time is short, sports and spectacles are sufficient as relaxation for most; but with longer periods of freedom normal people will need something in addition. Some will doubtless be attracted by the study of natural history. Men and women of the Forces and evacuee children will be unlikely to be content to stay put, and we shall probably have a greater number exploring the countryside than ever before. Let us have wide open spaces, call them what you will, let us keep them so that they will ever show what Great Britain was by showing what she is, let us realize that it is to the community's interest to preserve wild life, be it plant, bird, animal or insect: then when we have the same pride in our natural possessions as we have in our race we shall have gone far along the way to preserving our flora.

\section{OB IT UAR IES}

Mr. W. H. Caldwell
WILliam HAY CALDWELL died at Morar Lodge, Inverness-shire, on August 28. In the 'eighties he was notable as an original young Cam. bridge zoologist who had revolutionized the process of cutting paraffin sections. Born at Portobello in 1859, he went from Loretto to Gonville and Caius College, Cambridge, in 1877, and attended Francis Maitland Balfour's lectures on animal morphology. He was scholar of his College during 1878-83, and obtained a first class in the Natural Sciences Tripos of 1881, beside Walter Gardiner the botanist, who survived him three days'. Research on the develop- ment of Phoronis occupied his first graduate year, which was marred by Balfour's untimely death on the Alps (July 1882) - thirty years old and of world- wide reputation.

Adam Sedgwick, aged twenty-seven, manfully faced the task of carrying on the school founded by Balfour. Balfour's professorship had been created for him and died with him when he had held it seven weeks; so when as a freshman I entered the new Morphological Laboratory, just completed by the University for Balfour but never seen by him, Sedgwick, Trinity lecturer, presided over it. Caldwell was appointed University demonstrator of comparative anatomy in succession to J. J. Lister ; Sedgwick and Caldwell, with fourteen-year-old "John" for laboratory boy, forming the entire staff.

So I found the advanced lectures on invertebrates being delivered by an attractive young man, on the tall side of middle height and well made, with finely cut features, fair wavy hair and a carefully twisted little fair moustache; this was Caldwell. On the 